\title{
Severe Demodex Infestation of a Coal Miner
}

\author{
Bir Kömür Maden İşçisinde Ağır Demodeks Enfestasyonu
}

\author{
Arzu Karataş Toğral', Mahmut Altındal², Özgül Muştu Koryürek³ , Engin Tutkun ${ }^{4}$, Ömer Hınç Yılmaz \\ ${ }^{1}$ Clinic of Dermatology, Ankara Occupational Diseases Hospital, Ankara, Turkey \\ ${ }^{2}$ Clinic of Internal Diseases, Ankara Occupational Diseases Hospital, Ankara, Turkey \\ ${ }^{3}$ Clinic of Dermatology, Ankara Education and Research Hospital, Ankara, Turkey \\ ${ }^{4}$ Clinic of Toxicology, Ankara Occupational Diseases Hospital, Ankara, Turkey
}

\begin{abstract}
We report a case of Demodex infestation in a 35 year old coal miner presenting with a 5 year history of scally papulopustular eruption on his face. He had been working inunderground coal tunnels in a humid- hot- dusty environment and he had been used to bath twice a day with hot water and multiple cleaners. The patient was treated successfully with oral metronidazol, topical permethrin, topical steroids and avoidance of undergraund mining. We believe his occupational environment made him prone to infestation by changes in sebum composition and/or viscosity, his bath habituation facilitated infestation, damaging the epidermal barrier function and his previous treatments exaggerated his infestation. During evaluation of the patient, specific occupational factors and habituations will be related with higher succession rates of treatment. We need to conduct further studies in order to draw a definite conclusion about the effect of the occupational environment on Demodex infestation. (Turkiye Parazitol Derg 2013; 37: 295-8)
\end{abstract}

Key Words: Demodex, occupation, coal miner, sebum

Received: 19.05 .2013

Accepted: 11.07.2013

\section{ÖZET}

Bir kömür maden işçisinde 5 yıldır yüzde soyulma, pullanma ve papülopüstüler döküntüyle seyreden Demodeks enfestasyonu olgusu sunuldu. Hasta yeraltında sıcak-nemli-tozlu bir ortamda çalışıyor ve hastalığının kirlilikten olduğu düşüncesi ile günde iki kez sıcak su ve çeşitli temizleyicilerle banyo yapıyordu. Hasta yeraltı çalışmasından uzaklaştırıldı, oral metronidazol, topikal permetrin ve topikal steroidlerle başarılı bir şekilde tedavi edildi. Hastanın çalışma ortamının özelliklerinin sebumun yapı ve/veya viskositesini değiştirerek enfestasyona yatkınlık sağladığını, hastanın banyo şekli alışkanlığının da epidermal bariyerin yapısını bozarak bunu kolaylaştırdığını geçmişte aldığı tedavilerin enfestasyonu şiddetlendirdiğini düşünüyoruz. Hastaların değerlendirilmesi esnasında mesleki faktörler ve kişisel alışkanlıkların göz önünde bulundurulmasının yüksek tedavi başarı oranlarını sağlayacağı kanaatindeyiz. Mesleki faktörlerin Demodeks enfestasyonu üzerindeki etkisinin daha net anlaşılabilmesi için ileri çalışmalara ihtiyaç vardır. (Turkiye Parazitol Derg 2013; 37: 295-8)

Anahtar Sözcükler: Demodeks, meslek, kömür maden işçisi, sebum

Geliş Tarihi: 19.05.2013

Kabul Tarihi: 11.07.2013

\section{INTRODUCTION}

Demodex mites are common saprophytic ectoparasites of the pilosebaceous unit in mammals (1). In humans two species of parasite - Demodex folliculorum (DF) and Demodex brevis (DB)- have been identified. They inhabit the piloseba- ceous unit, DF is located at the infundibulum of hair follicle, DB is located deeper at the sebaceous glands and ducts and utilizes sebum and follicular cells as nourishment. Demodex mites are known inhabitants of the pilosebaceous units in mammals, but proliferation of the mite population

Address for Correspondence / Yazışma Adresi: Dr. Arzu Karataş Toğral, Clinic of Dermatology, Ankara Occupational Diseases Hospital, Ankara, Turkey. Phone: +90 5052911575 E-mail: arzukrts@yahoo.com doi:10.5152/tpd.2013.3181 


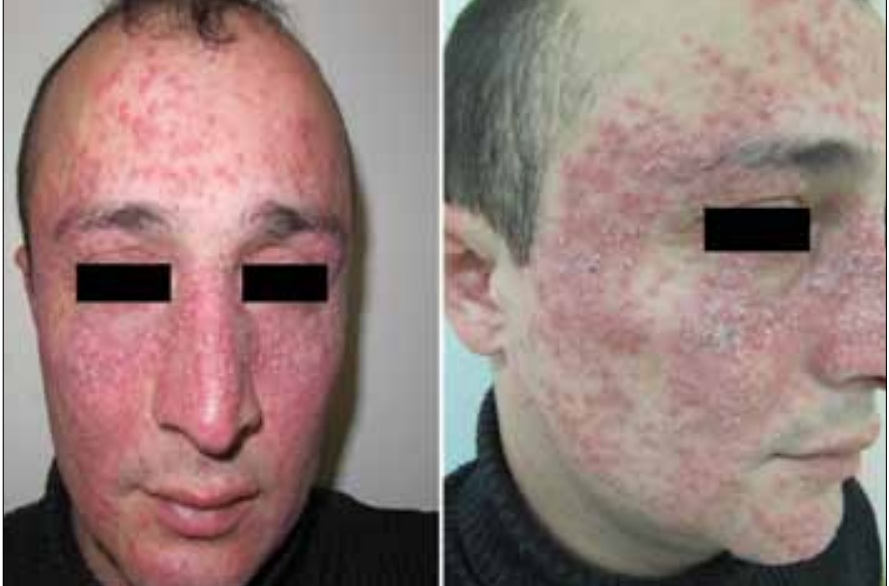

Figure 1. Thirty five-year-old coal miner with erythematous and papulopustular eruption with scaling on his face

or penetration into the dermis is pathologic and regarded as an infestation. The nose, cheeks, forehead, temples, chin, external ear tract and eyelids are the predilection sites for mites (2). Infestation with Demodex is rare in childhood and the prevalence increases with age (3). The location and age distribution of infestation is assosiated with sebaceous gland activity and the lipophylic characateristics of the mite $(1,4-7)$. Currently, Demodex infestation is accepted as a causative or at least an aggravating factor for many dermatologic diseases (4, 8-11), but some authors consider it as a coincidence $(12,13)$. We report a coalminer with a five-year history of eruptions on his face, diagnosed as mixed (rosacea-like demodicidosis and granulomatous rosacea-like-demodicidosis gravis) Demodex infestation, and treated successfully with suspension from work and medication.

A 35-year-old coal miner complained of a slightly pruritic eruption on his face of four years duration. On dermatologic examination erythema, scaling and papulopustular eruption were seen on his face, more significantly at the malar and temporal areas (Figure 1). Lesions had been present since he started work as a coal miner in 2008. He was diagnosed with contact dermatitis, acne rosacea and lupus miliaris disseminatus faciei (due to a skin biopsy reported as granulomatous dermatitis) and treated with systemic and topical corticosteroids, oral doxycycline, oral retinoids and multiple topical drugs for acne. He reported that the lesions responded partially to all treatments and regressed noticeably during long holidays but relapsed after cessation of drugs or on return to mining. An occupational health physician was suspicious of an occupational dermatosis and referred him to our hospital.

He was working in coal tunnels in a humid, hot and dusty environment. Since he had a thought that he had an infectious disease due todirt, he used to shower twice a day with hot water and multiple cleaners. He scrubbed his body with a loofah every time.

The diagnosis was made by detecting Demodex mites on the skin by Standardized Skin Surface Biopsy (SSSB) (a drop of rapidly drying glue is dropped on the lesions and then touched with a glass slide, after the glue dried, slide was pulled off, the sample was covered with a coverglass and examined for parasites by

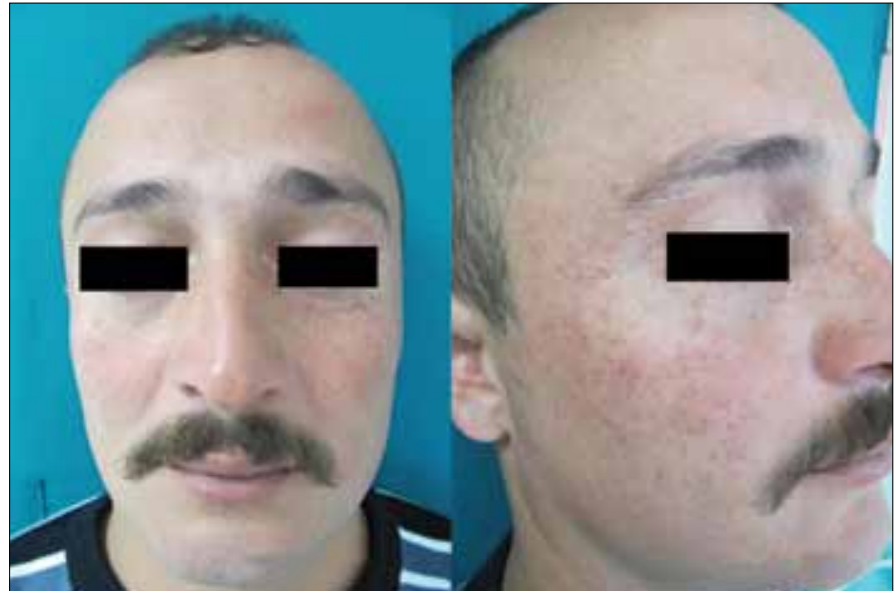

Figure 2. The patient had complete clearing of the lesions with no recurrence after 3 months

light microscopy ). SSSB slides collected from the temples, forehead, cheeks and chin. Over 30 parasites per $\mathrm{cm}^{2}$ were detected on each slide by light microscopy examination.

He was treated with metronidazol 500 mg twice a day (for 3 weeks), topical permethrin 5\% lotion every other day (for 3 weeks) and topical steroid (for 1 week). He was suspended from work for three weeks. Three weeks later, he had complete clearance of the lesions. SSSB was repeated, fewer than 5 parasites per $\mathrm{cm}^{2}$ were detected in all 6 regions of face. At his control examination after 3 months, his face was still completely cleared of the lesions, with no recurrence (Figure 2).

\section{DISCUSSION}

Demodex mites are common saprophytic ectoparasites of the pilosebaceous unit. Presence of mites on the skin may be asymptomatic or can be the cause or aggravating factor of some dermatological diseases. The studies concluded that infestation rate was asssociated with age (highest in 20-30 year old), skin type (higher in oily and mixed type of skin) and some underlying dermatological diseases $(8,13,14)$. The association with individual hygienic practices is controversial. Our patient was 35 years old, an age with matured and active sebaceous glands. He used to bath with hot water and multiple cleaners twice a day. We believe that these types of extreme cleaning habits made his skin skin more prone to Demodex infestation by either diminishing the skin barrier function and / or causing irritant/allergic contact dermatitis.

Demodex mites may reside on healthy skin as a member of normal skin flora. The difference between infestation and normal flora is the number of parasites. Pathogenic infestation is defined as the presence of more than five parasites per $\mathrm{cm}^{2}$, smaller numbers of parasites are usually accepted as a coincidence. Yazar et al. (15) found that $2.9 \%$ of healthy students in high school $(n=171)$ were infested by Demodex mites. Some investigators concluded that underlying dermatologic conditions induce susceptibility for infestation, some did not $(1,4,6$, $8,9,13-16)$. The authors usually explain this susceptibility with damage of concomitant disease to the epidermal barrier. Aycan et al found that patients with rosacea were more prone to 
infestation than patients with acne and allergic diseases. Aycan et al. (14) demonstrated that both the rate of Demodex infestation positivity and the parasite density were higher in patients with seborrhoeic dermatitis than the healthy control group. Baysal et al. (17) confirmed the association between acne vulgaris and Demodex infestation.

Karincaoglu et al. (18) considered that Demodex infestation may present with non-specific clinical features (facial itching, erythema, papulo-squamous or papulopustular lesions), and with acaricidal treatment both the lesions and density of parasites declines. Our patient claims that he had no dermatologic disease before he started mining, and after acaricidal treatment we did not detect any accompanying dermatologic disease. The decrease in number/density of parasites were coupled with regression of lesions. In our case we believe that Demodex played a major role in the development of the clinical features rather than being an accompaniment. In our opinion, the telangiectasias which became prominent after the treatment were secondary to topical steroids which the patient had used before our treatment.

Cunliffe et al. $(19,20)$. demonstrated that the sebum excretion rate increases by $10 \%$ with an increase in temperature of $1^{\circ} \mathrm{C}$. Since their experiment time was as short as 90 minutes, the authors emphasized that this situation was due to alterations in sebum viscosity. Qui et al. (21) implied that active follicles excrete more sebum during summer (hot and high relative humidity) than winter (cold and low relative humidity), although the difference is not statistically significant. Rosacea has been considered as the most relevant dermatitis with Demodex infestation. Suprisingly, acne patients are usually less prone to Demodex infestation than patients with rosasea, despite the increase of sebum secretion. Papulopustular rosacea patients have an abnormal fatty acid composition of their skin surface lipid layer, with increased levels of linoleic acid and myristic acid, as well as reduced levels of specific saturated fatty acids (22). In contrast, acne patients have been shown to have low levels of linoleic acid in their sebum (23). The changes in sebum composition or viscosity may facilitate mite infestation by supplying a suitable habitat for nourishment. With this evidence, it is suggested that it could be the quality, not the quantity of sebum, that plays a role in Demodex infestation. Our patient reported that the lesions had regressed noticeably during long holidays but had relapsed when he returned to mining in tunnels. As the composition and viscosity of sebum are affected by heat and humidity, it is possible that avoidance of high temperature and humidity, has a protective effect by changes in sebum ingredients.

\section{CONCLUSION}

Dolenc-Voljc et al. (24) demonstrated that patients with peroral dermatitis who had been treated with topical steroids in the past, had a significantly higher mite density than both the healthy controls and the patients with peroral dermatitis who had not received topical steroids. In our case, repeated use of topical steroidsprobably played a role in the increase of mite population.
During evaluation of patients with dermatologic problems, specific occupational factors and habituations should be taken into account for higher succession rates of treatment. To draw a definite conclusion about the effect of occupational environment, we need to conduct further studies.

Conflict of Interest: No conflict of interest was declared by the authors.

Financial Disclosure: The authors declared that this study has received no financial support.

Peer-review: Externally peer-reviewed.

Informed Consent: Written informed consent was obtained from patient who participated in this case.

Author Contributions: Concept - A.K.T., Ö.M.K.; Design - A.K.T., M.A.; Supervision - Ö.H.Y.; Funding - A.K.T., M.A.; Materials A.K.T.; Data Collection and/or Processing - A.K.T.; Analysis and/ or Interpretation - A.K.T., Ö.M.K.; Literature Review - A.K.T., E.T.; Writing - A.K.T., M.A.; Critical Review - E.T., Ö.H.Y.

\section{Çıkar Çatışması: Yazarlar çıkar çatışması bildirmemişlerdir.}

Finansal Destek: Yazarlar bu çalışma için finansal destek almadıklarını beyan etmişlerdir.

\section{Hakem değerlendirmesi: Dış bağımsız.}

Hasta Onamı: Yazılı hasta onamı bu olguya katılan hastadan alınmıştır.

Yazar Katkıları: Fikir - A.K.T., Ö.M.K.; Tasarım - A.K.T., M.A.; Denetleme - Ö.H.Y.; Kaynaklar - A.K.T., M.A.; Malzemeler A.K.T.; Veri toplanması ve/veya işlemesi - A.K.T.; Analiz ve/veya yorum - A.K.T., Ö.M.K.; Literatür taraması - A.K.T., E.T.; Yazıyı yazan - A.K.T., M.A.; Eleştirel Inceleme - E.T., Ö.H.Y.

\section{REFERENCES}

1. Baima B, Sticherling M. Demodicidosis revisited. Acta Derm Venereol. 2002; 82: 3-6. [CrossRef]

2. Zhao YE, Hu L, Wu LP, Ma JX. A meta-analysis of association between acne vulgaris and Demodex infestation. J Zhejiang Univ Sci B 2012; 13: 192-202. [CrossRef]

3. Zomorodian K, Geramishoar M, Saadat F, Tarazoie B, Norouzi M, Rezaie S. Facial demodicosis. Eur J Dermatol 2004; 14: 121-2.

4. Karincaoglu Y, Tepe B, Kalayci B, Atambay M, Seyhan M. Is Demodex folliculorum an aetiological factor in seborrhoeic dermatitis? Clin Exp Dermatol 2009; 34: 516-20. [CrossRef]

5. Basta-Juzbasic A, Subic JS, Ljubojevic S: Demodex folliculorum in development of dermatitis rosaceiformis steroidica and rosacea-related diseases. Clin Dermatol 2002; 20: 135-40. [CrossRef]

6. Forton F, Germaux MA, Brasseur T, De Liever A, Laporte M, Mathys $C$, et al. Demodicosis and rosacea: epidemiology and significance in daily dermatologic practice. J Am Acad Dermatol 2005; 52: 74-87. [CrossRef]

7. Zhao YE, Wu LP, Peng Y, Cheng H.Retrospective analysis of the association between Demodex infestation and rosacea. Arch Dermatol 2010; 146: 896-902.

8. Zhao YE, Peng $Y$, Wang $X L$, Wu LP, Wang $M$, Yan $H L$, et al. Facial dermatosis associated with Demodex: a case-control study. J Zhejiang Univ Sci B 2011; 12: 1008-15. [CrossRef]

9. Türk M, Özturk I, Sener AG, Kücükbay S, Afşar I, Maden A. Comparison of incidence of Demodex folliculorum on the eyelash 
follicule in normal people and blepharitis patients. Turkiye Parazitol Derg. 2007; 31: 296-7.

10. Jarmuda S, O'Reilly N, Zaba R, Jakubowicz O, Szkaradkiewicz A Kavanagh K. Potential role of Demodex mites and bacteria in the induction of rosacea. J Med Microbiol 2012; 61: 1504-10. [CrossRef]

11. El-Bassiouni SO, Ahmed JA, Younis Al, Ismail MA, Saadawi AN, Bassiouni SO. A study on Demodex folliculorum mite density and immune response in patients with facial dermatoses. J Egypt Soc Parasitol 2005; 35: 899-910.

12. Kemal M, Sumer Z, Toker MI, Erdogan H, Topalkara A, Akbulut M. The Prevalence of Demodex folliculorum in blepharitis patients and the normal population. Ophthalmic Epidemiol 2005; 12: 287-90. [CrossRef]

13. Okyay P, Ertabaklar H, Savk E, Erfug S. Prevalence of Demodex folliculorum in young adults: relation with sociodemographic/hygienic factors and acne vulgaris. J Eur Acad Dermatol Venereol 2006; 20: 474-6. [CrossRef]

14. Aycan OM, Otlu GH, Karaman U, Daldal N, Atambay M. Frequency of the appearance of Demodex sp. in various patient and age groups. Turkiye Parazitol Derg 2007; 31: 115-8.

15. Yazar S, Özcanu H,Cetinkaya U. Investigation of Demodex sp. using cellophane tape method among university students. Turkiye Parazitol Derg 2008; 32: 238-40.

16. Zhao YE, Guo N, Xun M, Xu JR, Wang M, Wang DL. Sociodemographic characteristics and risk factor analysis of Demodex infestation (Acari: Demodicidae). J Zhejiang Univ Sci B 2011; 12: 998-1007. [CrossRef]
17. Baysal V, Aydemir M, Yorgancıgil B,Yıldırım M. Akne Vulgaris Etyopatogenezinde Demodex folliculorum'ların Rolünün Araştırılması. Türkiye Parazitol Derg 1997; 21: 265-8.

18. Karincaoglu Y, Bayram N, Aycan Ö,Esrefoglu M. The Clinical Importance of Demodex folliculorum Presenting with Nonspecific Facial Signs and Symptoms. J Dermatol 2004; 31: 618-26.

19. Cunliffe WJ, Burton JL, Shuster S. The effect of local temperature variations on the sebum excretion rate. $\mathrm{Br} J$ Dermatol. 1970; 83: 650-4. [CrossRef]

20. Williams M, Cunliffe WJ, Williamson B, Forster RA, Cotterill JA, Edwards JC. The effect of local temperature changes on sebum excretion rate and forehead surface lipid composition. Br J Dermatol 1973; 88: 257-62. [CrossRef]

21. Qiu H, Long X, Ye JC, Hou J, Senee J, Laurent A, et al. Influence of season on some skin properties: winter vs. summer, as experienced by 354 Shanghaiese women of various ages. Int J Cosmet Sci 2011; 33: 377-83. [CrossRef]

22. Ni Raghallaigh S, Bender K, Lacey N, Brennan L, Powell FC. The fatty acid profile of the skin surface lipid layer in papulopustular rosacea. Br J Dermatol 2012; 166: 279-87. [CrossRef]

23. Downing DT, Stewart ME, Wertz PW, Strauss JS. Essential fatty acids and acne. J Am Acad Dermatol 1986; 14: 221-25. [CrossRef]

24. Dolenc-Voljc M, Pohar M,Lunder T. Density of Demodex folliculorum in perioral dermatitis. Acta Derm Venereol 2005; 85: 211-15. [CrossRef] 